\title{
Framing Analysis: Corona Virus News on Kompas.Com
}

\author{
Wayan Tantre Awiyane ${ }^{1}$, Suraya Mansur ${ }^{2}$ \\ \{wayantantre96@gmail.com ${ }^{1}$, suraya.suraya@mercubuana.ac.id ${ }^{2}$ \} \\ Universitas Mercu Buana, Jakarta, Indonesia ${ }^{12}$
}

\begin{abstract}
This research aims to dig deeper into how Kompas.com framing the news of Corona Virus and also analyze the news value. It applies qualitative approach and Robert N Entman Framing analysis method as the picture of social phenomena in Corona Virus news. Kompas.com is chosen as the research subject, while the news of Corona Virus on March to April 2020 become the research object. The data are collected by using documentation technique and purposive sampling, selecting sample based on characteristics perceived as representing to be used in this research. The sample consists of 38 news. The results shows that in reporting Corona Virus, Kompas.com create diverse narrations in order attract news readers to the information's reported. There are two visible elements, impact and Human Interest. Kompas.com always sets forth ideology of capitalist economy in framing over the news of Corona Virus. However, Kompas.com is trying to wrap the news content with a polite and wise language to guard its professionalism as a mass media which accentuates universal, intelligence, and professionalism value.
\end{abstract}

Keywords: Framing, News, Corona Virus, Kompas.Com, Economy of Capitalist Media

\section{Introduction}

Media is constantly trying to create news with sales value because mass media also have business line and economic interest (profit). In other words, media are demanded to meet the taste of public. Consequently, different point of view is inevitable among mass media in reporting an event. In wrapping news of an event, media have their own distinctive way influenced by their ideology. Nowadays, mass media are inseparable from people life because mass media, either printed or electronic, have become a life necessity. Through mass media, people can at least obtain entertainment and factual news of various events happened around the world. The difference in reporting a news in various mass media is also influenced by background of the journalist from the media concerned [1].

The development of Corona Virus information in Indonesia can be seen on Kompas.com as one of online media. Related to this matter, Media do Framing by selecting certain issues and ignoring the rests; accentuating the aspect of certain issues selected by applying various discourse strategy, striking placement (on headline, front page, or last page), repetition, using graphic to support and strengthen the accentuation, using certain labels while describing person or event reported [2]. 
Up to January 26, 2020, 1.320 cases are globally confirmed in 10 countries with 41 deaths (CFR 3,1\%). In China, 1.297 cases are confirmed (including Hongkong, Taiwan, and Macau) with 41 deaths (39 deaths in Hubei Province, 1 death in Hebei Province, 1 death in Heilongjiang Province), Japan (3 cases), Thailand (4 cases), South Korea (2 cases), Vietnam ( 2 cases), Singapore ( 3 cases), USA ( 2 cases), Nepal (1 case), France (3 cases), Australia ( 3 cases). Among these cases, there are several medical forces reported as infected. Up to January 24 2020, WHO reports that infection among human limited (in family contact) has been confirmed in most cities of Wuhan, China and other countries (Health Ministry of Republic of Indonesia, 2020). WHO has also confirmed that covid - 19 is a pandemic disease caused by corona virus [3], [4], [5], [6].

Based on its publication, Kompas.com initially publishes corona virus news on January 2, 2020 (https://sains.kompas.com/read/2020/02/01/200500923/pertama-kali-ditemukan-kasusvirus-corona-menular-sebelum-gejalanya-muncul). Whereas, the outbreak of Corona Virus in Indonesia is revealed on February 14, 2020. An Indonesia citizen, 31 years old, is presumably infected while she is in a restaurant in Jakarta. She is infected by a Japanese citizen who is at the same place at the moment. The Indonesian and Japanese citizen are discovered in a close contact [4].

A close contact is a distance that allows the virus to infect others. Then, patient 1 is making contact with patient 2 , who is her own mother. The mother has been infected by the virus while taking care of her sick daughter. The minister of health, Terawan Agus Putranto states that these two patients live in Depok, West Java (https://nasional.kompas.com/read/2020/03/09/05280011/kronologi-dan-urutan-munculnya6-orang-positif-virus-corona-di-indonesia). Kompas.com has published the news of corona virus in Indonesia. However, at the beginning of its outbreak, Indonesia has not been one of infected countries. On March 2, Indonesian President Joko Widodo announces that there are two citizens confirmed as positive of infected by corona virus. According to him, two Indonesian citizens (WNI) are making contact with Japanese citizen visiting Indonesia (https://nasional.kompas.com/read/2020/03/02/11265921/breaking-news-jokowi-umumkandua-orang-di-indonesia-positif-corona).

The information's keep developing and Kompas.com publishes for the next time regarding the total number of corona virus infection which is growing bigger day by day. Despite, the total number of patients confirmed as recovered from corona virus is also increasing. As stated in SCMP, up to Tuesday (3/3/2020) morning, the total of infection case that has been recorded all around the world is 90.872 cases. From these thousand cases, 48.002 people have been confirmed as recovered from corona virus. Meanwhile, the total death victim of corona virus has reached 3.117 people (https://www.kompas.com/tren/read/2020/03/03/091500465/update-virus-corona-di-seluruhdunia-tembus-73-negara-48002-sembuh-3117). There are also numerous researches of corona virus or covid-19 conducted such as a research by [7] who state that covid-19 virus is believed as epidemic disease. Besides, [8] have done a research concerning psychosocial effect of covid-19. Other researches are done by [9] about public health related to covid-19, also by [10], and [11]. Meanwhile, this research focuses on news framing of covid-19 on online media. It will also be related to the media background in publishing the issue. One of them is because media economics embraced by the media.

Media economics is a combination between Economics and media study which emphasizes on how the change of economic pressures affect the management of media company in making decision. Robert Picard mentions economic emphasis of media is on 
how media actors can satisfy the need of audiences, advertiser and people in general over entertainment information based on the existing sources [12], [13].

In its development, study of media economics results in approaches lead to media study in a more specific way. Picard [14], [15] classifies them into three, they are: industry and market studies, company studies, and effect studies. (1) Industry and Market Studies, Industrial organization, Demand, Forecasting, Consumer spending, Niche, Concentration, Relative constancy, Communications policy. (2) Company Studies: Business strategy, Communication Organization and Culture, Cost structure, Financing and investment, Financial performance, Productivity, Diversification. (3) Business strategy: Organization and Communication Culture, Cost structure, Financing and investment, Financial performance, Productivity, Diversification. (4) Effects Studies: Dependency, Financial commitment, Quality and diversity, Globalization and trade balances, Consumer and social welfare. (5) Dependency, Financial Commitment, Quality and Diversity, and Globalization and trade balances, Consumer and social welfare.

Peter L. Berger [16] argues that reality does not just happen, but it is shaped and constructed. The final result is that the same reality can be differently perceived by every single person which depends on the construction in the reality itself [17]. Mass media produce messages as the result of reality construction [17]. In witnessing that kind of condition, Hamad [18] asserts that thus media is also playing a role in constructing reality. Reality construction is not just shaped by the way a journalist perceives the reality, but also the political life which the media are in. The political system applied by a country also defines work mechanism of mass media in the country which influences the way of mass media in constructing reality. The development of mass media enables people to enjoy the news from everywhere, including online media. There are several benefits gained from online journalism, one of them is immediacy. Immediacy enables the information's to be quickly and directly delivered to the audiences. Therefore, they do not have to wait for publication as done by newspaper [19].

In analyzing how framing is done by media, there is a framing instrument as declared by Entman [20]; [21]; [22]; [23]; [24]; [25], which can describe how an event is interpreted and signified by journalists. Entman divides framing instrument into four elements as follows: (1) Define problems is framing main element emphasizes on how an event is perceived by a journalist. The same event can also be differently understood. Different frame will shape different reality. (2) Diagnose causes is a framing element used to frame every actor/cause in an event. In this case, the cause can be what or who. (3) Make moral judgement is a giving argumentation element or justification that will support definition and cause of a problem. (4) Treatment recommendation emphasizes on solution. This element summarizes solution desired by journalists by considering who cause the problem and how the event is desired to be seen [19].

Referring to the thinking basis, it is obvious that media partakes in defining how reality should be understood, how the reality is elaborated in a certain way to the public. Among the diverse functions of media in defining reality, the primary function of media in ideology is as social integration mechanism. Media functions to guard group values, and to control how these values are run. News is a report or notice about how an event is happening or a general situation that just happens reported by a journalist in mass media. Event or situation become the main trigger of a news. It means that an event and situation are fact or condition that actually happen, not a conjecture or fiction of the writer.

News is written based on reality or fact. The fact written has to fulfill the elements of news text. According to [27], news is fact worthy to be reported and has to fulfil the element 
of $5 \mathrm{~W}+1 \mathrm{H}$ questions. $5 \mathrm{~W}+1 \mathrm{H}$ is the abbreviation of what, where (where the event takes place), when (when the event takes place), who (who is involved in the event), why (why the event takes place), and how (how the event takes place) [28], [29].

A news is interesting if it has news value. Several elements of news value which become the basis of an event reporting are: [30], [31] (1) Timeliness, news is similar with an ice cream that can easily melts. As the time passes, the value of a news is degrading. Competition needs a speed. (2) Proximity, news of an event contains proximity element to the readers, will draw attention. (3) Prominence, news covers an event occurs to either people or famous places. (4) Consequence, "news" is "history in a hurry". Measuring the impact of an event, it has a vast impact in society. (5) Human interest, news attracts readers as sympathy and empathy. (6) Conflict, as in war event, demonstration or crime are example of element in news reporting. (7) Sex often becomes the main element in a news. Nevertheless, sex also often becomes an additional element for a certain news. (8) Progress, a spacecraft planned to land on Mars is being built in America. It is everything that happens [32]. Based on the background, research questions can be formulated as follows: How is Framing on Kompas.com in reporting Corona Virus news? and how is the news value of Corona Virus on Kompas.com.

\section{Research Method}

In this research, the researcher uses Constructivist paradigm with qualitative approach and Robert N. Entman framing analysis method. Framing analysis is one of text and language analysis categories in qualitative research. It refers to this research which focuses on news framing of Corona Virus on Kompas.com as a news platform since March to April 2020. The data are collected by applying documentation technique that is done by studying and taking note of significant parts. The type of documentation used in this research is external document in form of news disseminated by online media. In this case, the researcher does the documentation by capturing news on a news portal, Kompas.com, published on March up to April 2020 which are 38 news in total.

\section{Results and Discussion}

\subsection{Result}

This research uses news on online media called Kompas.com regarding Corona Virus. As Corona Virus is chosen as the study theme, the news is chosen based on whether or not it reports corona virus. The followings are the news of corona virus on Kompas.com taken to be analyzed:

Table 1. Framing of Corona Virus News on Kompas.com on March-April 2020

\begin{tabular}{|c|l|}
\hline Define Problems & $\begin{array}{l}\text { Kompas.com perceives the core problem is begun from } \\
\text { the vast outbreak of corona virus in Wuhan, the infected } \\
\text { patient and virus outbreak in Indonesia, and also the } \\
\text { recovered patient in Indonesia from the virus. }\end{array}$ \\
\hline Diagnose Causes & $\begin{array}{l}\text { Kompas.com sees that corona virus has infected } \\
\text { Indonesian citizen and covid-19 has caused death of }\end{array}$ \\
\hline
\end{tabular}




\begin{tabular}{|c|l|}
\hline & Indonesian citizen. \\
\hline $\begin{array}{c}\text { Make Moral } \\
\text { Judgement }\end{array}$ & $\begin{array}{l}\text { Moral decision announced by Kompas.com is that people } \\
\text { should not be too panic in facing pandemic situation in } \\
\text { both Indonesia and around the world. }\end{array}$ \\
\hline $\begin{array}{c}\text { Treatment } \\
\text { Recommendation }\end{array}$ & $\begin{array}{l}\text { Kompas.com considers government instruction to start } \\
\text { clean and healthy life, stay at home, wear face mask, and } \\
\text { comply with health protocol as the resolution in the } \\
\text { news. }\end{array}$ \\
\hline
\end{tabular}

\section{Analysis}

Framing on Kompas.com during March-April 2020 asserts that the outbreak of corona virus is extremely rapid, so that the world is now dealing with lethal threat of the virus. The narration reported by Kompas.com states that now the world is staying alert to avoid corona virus that has invaded Indonesia and caused death. Kompas.com believes that the best way of saving people from being infected by the virus is by staying at home for a while until the government confirms that the condition is already back to normal.

Based on above understanding, the researcher sees that there are several elements missing in the information reported by Kompas.com which is related to corona virus outbreak in Wuhan China and Amerika in releasing the number of its death citizens after being infected by corona virus. The news is not based on direct reporting of the Chinese or American Government which means that the information released still strongly uses journalist's point of view. Besides, Kompas.com does not clearly give educative information to the public regarding the preventive way or effort to protect themselves from being infected by corona virus.

While we discuss about pandemic, normally the news should include the solution or a way out for Indonesian people who have not been infected by the virus. Besides, Kompas.com does not bases its news on WHO's decision regarding its statement as the World Health Organization which is morally and fully responsible to supervise people's health all around the globe. Economic element refers to media industry on Kompas.com can be seen from production, content and audience. When we observe the news published by Kompas.com, the narration constructed is vividly seen, the news sources cited from media which publishes news concerning corona virus are very close to empathy and their impact to people in general. From the impact of corona virus outbreak that has changed from epidemic to pandemic level around the world, Indonesia becomes one of impacted countries, audiences are people or public, the information receiver about the update of corona virus outbreak.

Therefore, from the economic side, Kompas.om writes the news briefly. If being observed from the working system of digital platform, Kompas.com gain its main income from advertising. It becomes the main focus while talking about the income of digital media that is purely from advertisement and total viewer of the news published. It is related to the goal of industrial press, profit. This construction aspect is associated with how Kompas.com journalists present an event that is both relevant with what truly happens and what truly seen by public. In this aspect, Kompas.com decides what kind of item that can be seen and understood by public. Because of how complex and random events are, it requires 
Kompas.com to identify and classify them based on the suitability of social context which the public is in.

\subsection{Discussion}

Social reality construction, according to Berger [16], a reality does not occur by itself, but there is a person who creates it. In relation to the Berger's statement, in this research, Kompas.com is able to create social reality by publishing information about corona virus massively and consistently. Reality construction theory states that the information's reported by Kompas.com are built and shaped for a certain goal which is campaigning healthy and clean life habit in order to break the infection of covid-19. Prior to publishing a news, Kompas.com has decided the elements contained in the news.

An unattractive and valueless event are not newsworthy. It is also accordance with a research done by [33], [31] about news value. The result of this research is in line with a research conducted by [25] about news framing of covid based on millennial generation. A research of covid related to the media ideology [34], [21]. A research of covid-19 news framing regarding social reality construction that occurs in society [16], [35]. A social construction of clean and healthy life habit in the time of covid-19 pandemic [36].

\section{Conclusions}

Base on four steps of framing presented on Kompas.com, it can be concluded that: the step of defining issue based on editor's policy, by giving portion on the news of corona virus, people are expected to be able to perceive corona virus as humanitarian problem. Besides, Kompas.com news contains economic element because its narration consists of only $5 \mathrm{~W}+1 \mathrm{H}$. The news readers will constantly look for further news, thus Kompas.com can boost its views in each news reporting. This will result in the raise of the platform income.

Kompas.com pictures that the problem of reporting corona virus issue occurs naturally. Apart from it, in creating narration, Kompas.com is extremely minimizing the news report, so that there will be no complete description about corona virus. Kompas.com perceives the government decision is still very dependent on WHO as the World Health Organization. The country independence in dealing with this pandemic is still slow and the right strategy has not been found to overcome this case.

Kompas.com is reporting more information about corona virus in general. It does not especially report corona virus in Indonesia. In this research, there are two relevant elements of news value contained in corona virus reporting of Kompas.com which are impact and human interest. Media economics embraced by Kompas.com in reporting Corona Virus case is capitalist economy, which reflects industry of capitalist media. Media economics tends to prioritize profit interest for the media owner.

\section{References}

[1] C. Hayati Nainggolan, “Analisis Framing Pemberitaan Ganjar Pranowo dalam Kasus Korupsi E-KTP (Tribun News, Jawa Pos, dan Suara Merdeka Periode Agusutus-Nobember 2015 dan Maret 2017)," None, vol. 5, no. 4, pp. 1-8, 2017.

[2] A. Sobur, Analisis Teks Media. PT Rosdakarya, 2018. 
[3] G. L. Widyaningrum, "WHO Tetapkan COVID-19 Sebagai Pandemi Global, Apa Maksudnya?," National Geographic Indonesia, 2020. .

[4] E. Y. Saputra, "WHO Tetapkan Covid-19 Sebagai Pandemi, Apa Maksudnya?," Tempo, 2020.

[5] WHO, "Timeline of WHO's response to COVID-19," World Health Organisation, 2020. .

[6] WHO, "Advice for public," Who. 2020.

[7] T. P. Velavan and C. G. Meyer, "The COVID-19 epidemic," Tropical Medicine and International Health. 2020, doi: 10.1111/tmi.13383.

[8] S. Dubey et al., "Psychosocial impact of COVID-19," Diabetes Metab. Syndr. Clin. Res. Rev., 2020, doi: 10.1016/j.dsx.2020.05.035.

[9] C. A. Harper, L. P. Satchell, D. Fido, and R. D. Latzman, "Functional Fear Predicts Public Health Compliance in the COVID-19 Pandemic," Int. J. Ment. Health Addict., 2020, doi: 10.1007/s11469-020-00281-5.

[10] C. J. Greene, S. L. Burleson, J. C. Crosby, M. A. Heimann, and D. C. Pigott, "Coronavirus disease 2019: International public health considerations," J. Am. Coll. Emerg. Physicians Open, 2020, doi: 10.1002/emp2.12040.

[11] M. B. Isah et al., "Coronavirus Disease 2019 (COVID-19): Knowledge, attitudes, practices (KAP) and misconceptions in the general population of Katsina State, Nigeria," medRxiv, 2020, doi: 10.1101/2020.06.11.20127936.

[12] G. Doyle, Understanding Media Economics. 2014.

[13] G. Doyle, "Introduction to Media Economics," in Understanding Media Economics, 2014

[14] R. G. Picard and S. S. Wildman, Handbook on the economics of the media. 2015.

[15] R. G. Picard, "The rise and expansion of research in media economics," Commun. Soc., 2018, doi: 10.15581/003.31.4.113-119.

[16] P. Berger and T. Luckmann, "The social construction of reality," in Social Theory Re-Wired: New Connections to Classical and Contemporary Perspectives: Second Edition, 2016.

[17] Eriyanto, Analisis Framing. Yogyakarta: LKiS, 2009.

[18] I. Hamad, "Media Massa dan Konstruksi Realitas,” J. Pantau, p. 55, 1999.

[19] R. Mustika, "Analisis Framing Pemberitaan Media Online mengenai Kasus Pedofilia di Akun Facebook," J. Penelit. Komun., vol. 20, no. 2, pp. 135-148, 2017, doi: 10.20422/jpk.v20i2.159.

[20] R. M. Entman and N. Usher, "Framing in a Fractured Democracy: Impacts of Digital Technology on Ideology, Power and Cascading Network Activation," J. Commun., 2018, doi: 10.1093/joc/jqx019.

[21] R. M. Entman, J. Matthes, and L. Pellicano, "Nature, sources, and effects of news framing," in The Handbook of Journalism Studies, 2009.

[22] R. M. Entman, "Framing bias: Media in the distribution of power," J. Commun., 2007, doi: 10.1111/j.1460-2466.2006.00336.x.

[23] R. M. Entman, "Media framing biases and political power: Explaining slant in news of Campaign 2008," Journalism. 2010, doi: 10.1177/1464884910367587.

[24] R. M. Entman, "Framing: Til afklaring af et spredt paradigme," MedieKultur J. media Commun. Res., 2015, doi: 10.7146/mediekultur.v31i58.20002.

[25] K. M. Boer, M. R. Pratiwi, and N. Muna, "Analisis Framing Pemberitaan Generasi Milenial dan Pemerintah Terkait Covid-19 di Media Online," Commun. J. Ilmu Komun., 2020, doi: 10.15575/cjik.v4i1.8277.

[26] Panduan Menulis Berita. Malang: UMM Press, 2006.

[27] B. Carroll and B. Carroll, "Journalism in a Digital Age," in Writing and Editing for Digital Media, 2019.

[28] S. Mansur and S. A. Harsono, "Press Release by Medco E\&P Malaka on Serambi Indonesia Online News Coverage,” J. Messenger, 2020, doi: 10.26623/themessenger.v12i1.1412.

[29] S. Fox Lee, "News and announcements," Hist. Psychol., 2019, doi: 10.1037/hop0000132. 
[30] M. J. H. Serrano, A. Greenhill, and G. Graham, "Transforming the news value chain in the social era: A community perspective," Supply Chain Manag., 2015, doi: 10.1108/SCM-052014-0147.

[31] M. Bednarek and H. Caple, "Value added': Language, image and news values," Discourse, Context Media, 2012, doi: 10.1016/j.dcm.2012.05.006.

[32] S. Messing and S. J. Westwood, "Selective Exposure in the Age of Social Media: Endorsements Trump Partisan Source Affiliation When Selecting News Online," Communic. Res., 2014, doi: 10.1177/0093650212466406.

[33] N. L. R. Maha Rani, "Persepsi Jurnalis dan Praktisi Humas terhadap Nilai Berita,” J. ILMU Komun., 2013, doi: 10.24002/jik.v10i1.155.

[34] D. P. Calvillo, B. J. Ross, R. J. B. Garcia, T. J. Smelter, and A. M. Rutchick, "Political Ideology Predicts Perceptions of the Threat of COVID-19 (and Susceptibility to Fake News About It)," Soc. Psychol. Personal. Sci., 2020, doi: 10.1177/1948550620940539.

[35] J. Dreher, "The Social Construction of Power: Reflections Beyond Berger/Luckmann and Bourdieu," Cult. Sociol., 2016, doi: 10.1177/1749975515615623.

[36] A. Nurbaiti, I. Ihsani, S. T. Raharjo, and S. Humaedi, "PERILAKU HIDUP BERSIH DAN SEHAT MELALUI PROGRAM BERBAGI SEHAT OLEH PT UNILEVER," Pros. Penelit. dan Pengabdi. Kpd. Masy., 2020, doi: 10.24198/jppm.v6i3.26212. 